\title{
TITLE: HOW NOVELTY SEEKING INFLUENCES CUSTOMER CSR PERCEPTIONS
}

\section{ABSTRACT:}

Purpose - The authors aim to: 1) propose a causal model to understand the process of Corporate Social Responsibility (CSR) perception formation among customers; and 2) identify differences among innovative and conservative customers in that process.

Design/methodology/approach - A structural equation model is tested in a sample of 1,124 banking services customers in Spain. Also, a multisampling analysis is implemented in order to determine how novelty seeking moderates the process of CSR perception formation among customers.

Findings - Results confirm that customer CSR perceptions are directly and positively influenced by: 1) the congruence between CSR initiatives and corporate profile; 2) customer attributions of corporate motivations to engage in CSR; and 3) corporate credibility in developing CSR initiatives. Nonetheless, while innovative customers pay greater attention to corporate credibility than conservative customers when evaluating CSR initiatives, conservative customers evaluate the congruence of CSR initiatives and their attribution of altruistic motivations to a larger extent than innovative customers.

Practical implications - These findings suggest that companies should take into account customer novelty seeking when planning their CSR and communication strategies because highlighting different qualities of their CSR initiatives can have diverse effects for the success of corporate investments.

Originality/value - The greatest contribution of the paper is the study of the moderating role of novelty seeking in the process of customer CSR perception 
formation; previous scholars had long ignored this variable when evaluating customer perceptions.

KEYWORDS: Novelty seeking; CSR perceptions; C-CSR congruence; motivational attribution; corporate credibility

ARTICLE CLASSIFICATION: Research paper 


\section{INTRODUCTION}

A comprehensive definition of Corporate Social Responsibility (CSR) refers to all company activities that demonstrate the inclusion of social and environmental concerns in business operations and in interactions with stakeholders, as well as in accordance with the ambition levels of corporate sustainability. CSR is now a widely-accepted concept in academic literature. Since the appearance of this construct in the 1950s, and its further development in the 1960s and 1970s, there has been a progressive increase in the number of papers and research forums dedicated to the study of a normative definition of CSR, its dimensions and the theoretical and practical implications of CSR for businesses and society (Garriga and Melé, 2004). Researchers have also devoted many efforts to study the benefits of CSR for companies as well as its consequences on customer behaviour (Brown and Dacin, 1997; Sen and Bhattacharya, 2001; García de los Salmones et al., 2005; Pérez et al., 2013). Nonetheless, scholars have devoted much less attention to the study of the determinants of customer CSR perceptions and still little is known about what influences customers when evaluating the commitment of companies to CSR and forming their CSR perceptions (Rifon et al., 2004; Becker-Olsen et al., 2006; Bigné et al., 2009). Thus, this is a very new line of research that needs further exploration in academic literature (Rifon et al., 2004).

Along with this idea, it is also noticeable that the CSR notion has undergone a much slower introduction among practitioners than researchers. Nonetheless, whilst many CSR initiatives come under legal compliance (e.g., environmental legislation), businesses are now encouraged to go beyond this and assume roles previously occupied by the public sector (e.g., supporting education and becoming involved in the 
governance of communities) (Jenkins, 2006). Even though some countries have an extent tradition in the implementation of ethical business practices (e.g., organisations in the US are clear examples of business commitment to environmental and social practices), most companies in other countries have only started to think of CSR in the past two decades, when financial scandals and the loss of customer and societal trust in businesses have become evident (Argandoña, 1999). This is the case in many European countries, such as Spain, where companies have only started to design CSR strategies since the introduction of the United Nations' Global Compact in 1999 (Melé, 2004). Thus, the development of CSR in these countries is significantly new and its degree of implementation still moderate (Melé, 2004).

In this paper, the authors suggest that the recent development of CSR practices in Spain might influence the interaction of customers with this nascent business reality and the way in which they form perceptions of CSR. The authors draw on innovation diffusion theory (Rogers, 1995) to propose that, currently, customers only gradually integrate CSR into their perceptions of businesses, because this is still a relatively new construct for them, and not all customers are equally interested in CSR practices. According to innovation diffusion theory, the interest of customers in the novelties of markets depends on novelty seeking. Novelty seeking refers to customer values related to experimentalism and customer interest in trying new things and facing new stimulating challenges. Based on this variable, researchers have traditionally identified two customer types: conservative and innovative customers (McDonald and Alpert, 2007). Nevertheless, if few have been the scholars who have explored the determinants of customer CSR perceptions, no researcher has yet documented the usefulness of novelty 
seeking in understanding how customers form those CSR perceptions. New research is needed in this regard and this fact contributes to the originality of this paper.

Based on these ideas, the research goal in this paper is twofold: 1) to propose a causal model to understand the process of CSR perception formation among customers; and 2) to identify differences among conservative and innovative customers in that process. This study allows the determination of whether it is interesting for CSR managers to use novelty seeking as a criterion of market segmentation when targeting CSR initiatives toward customers.

The authors start by developing the conceptual framework of the paper. In doing so, they briefly revise previous literature concerning customer CSR perceptions and they describe the research gaps that justify the contributions of the present paper. Based on this review, the authors propose a causal model to understand the way customers form their CSR perceptions of companies and they also explore novelty seeking and its influence on the process of customer CSR perception formation. In the research design section, the authors justify the research context, sample and method applied in the study. The findings of the paper are divided into two sections: 1) firstly, the causal model to determine the process of customer CSR perception formation is tested; and 2) secondly, the model is further analysed by including novelty seeking as a moderator. The paper concludes with the discussion of the findings along with conclusions, limitations and future lines of research derived from the study. 


\section{CONCEPTUAL FRAMEWORK}

\subsection{Customer CSR perceptions: Literature review and research gaps}

Customer CSR perceptions refer to the image that customers hold of corporate responses to the general social concerns of stakeholder groups (Lai et al., 2010; Stanalad et al., 2011; Pérez and Rodríguez del Bosque, 2013). It is a concept that is gaining attention gradually both in the academic and professional literature because it boost customer-related benefits, such as satisfaction, repurchase intentions and customer willingness to recommend the company to other consumers (Sen and Bhattacharya, 2001; García de los Salmones et al., 2005). Thus, customer's opinions are considered to directly influence the design and effectiveness of corporate strategies and as so, their study is essential in the academic and business fields (Fukukawa et al., 2007).

Nonetheless, when studying this concept marketing scholars have almost exclusively focused on determining the impact of CSR perceptions on customer behaviour (Brown and Dacin, 1997; Sen and Bhattacharya, 2001; García de los Salmones et al., 2005; Matute et al., 2010; Tian et al., 2011; Pérez et al., 2013). For example, Brown and Dacin (1997) reveal that corporate product expertise is not the only factor that contributes to positive customer behaviour; CSR activities can also be used for this purpose. Similarly, García de los Salmones et al. $(2005,2009)$ also argue that customers are attracted towards their companies' CSR activities and that positive perception creates better evaluations of service performance that ultimately turn into positive loyalty intentions. Other scholars have focused on the effects of CSR perceptions on the honesty, integrity and credibility image of companies (Maignan and Ferrell, 2001; 
Sirdeshmukh et al., 2002). For example, Maignan and Ferrell (2001) argue that positive CSR perceptions can be a good source of customer trust and reduction of scepticism. CSR perceptions and trust are also significant variables in the cultivation of long-term affiliations between customers and companies (Swaen and Chumpitaz (2008).

On the contrary, few studies so far have attempted to understand the process by which customers construct CSR perceptions (Rifon et al., 2004; Becker-Olsen et al., 2006; Ellen et al., 2006; Bigné et al., 2009), and scholars have yet to present an integrative conceptual model that tests the formation process of CSR perceptions in the real context of companies marketing services. This gap identified in previous literature limits the currently available knowledge of CSR from a customer perspective and hampers the generation of effective managerial strategies based on economic, social and environmental concerns (Rifon et al., 2004). If practitioners knew which variables and concepts affect customer CSR perceptions they would be in a better position to provide customers with more appealing initiatives and they would be able to improve their marketing strategies and corporate performance substantially. Therefore, the purpose of the authors in this paper is to contribute to literature by exploring this process of customer CSR perception formation.

\subsection{The process of customer CSR perception formation}

To propose the conceptual model of this paper, the authors draw on the classic and widely-accepted model proposed by Rifon et al. (2004) to understand customer mental processing of CSR perceptions. The model considers three direct antecedents to customer CSR perceptions: C-CSR congruence, motivational attribution and corporate 
credibility. The results of their study confirm the value of a company's involvement in sponsoring CSR initiatives, which are perceived by customers as: 1) consistent with core business activities and products (C-CSR congruence); 2) altruistic in nature (motivational attribution); and 3) credible (corporate credibility).

Nonetheless, the authors identify three limitations in the paper by Rifon et al. (2004) that justify further study in this line of research. First, the study is based on a laboratory experiment, thus the perceptions of customers in a real market context are not evaluated. Second, the authors only study the reliability of the model in relation to the marketing of tangible products (i.e. Avon, Philip Morris, Reebok and Ortho). Further research in alignment with the proposals of Rifon et al. (2004) have tried to confirm their ideas in other service contexts (Becker-Olsen et al., 2006; Ellen et al., 2006; Bigné et al., 2009). All of these scholars confirm the findings of Rifon et al. (2004), although they only partially test the original model. For example, neither Ellen et al. (2006) nor BeckerOlsen et al. (2006) include corporate credibility as an antecedent to CSR perceptions. Similarly, Bigné et al. (2009) do not test the role of CSR perceptions in the model as they only test relationships between C-CSR congruence, motivational attribution and corporate credibility. The third limitation found in previous literature is the fact that feasible moderating effects on the process of CSR perception formation have been ignored.

Thus, the flaws that the authors identify in previous literature justify further study on the way customers form CSR perceptions. As already stated in the introduction, the aims of the authors in this paper are two-fold: 1) to corroborate the results of Rifon et al. (2004) in the context of a Spanish service industry (taking into consideration all the four 
variables initially considered by these scholars); and 2) to extend their findings by examining the role of novelty seeking on the way customers form CSR perceptions. In this section, the authors focus on the first research goal of the paper and for that purpose they develop six research hypotheses.

Firs, C-CSR congruence refers to customer perceptions of the similarity between the mission and goals of a company and the needs of its CSR initiatives and/or partners. The schema (Lynch and Schuler, 1994) and associative learning (Till and Nowak, 2000) theories explain the effects of C-CSR congruence on customer cognitive processes. According to these theories, learning is a mechanism by which customers establish relationships among concepts to produce an associative network in their memory. Through this network, customers learn about a concept through its relationship to other nodes in their memory. In the field of CSR, these stimuli are social causes, i.e. nonprofit organisations or institutions related to the promotion of CSR in the business arena. Thus, these theories point to improved corporate image as companies develop CSR initiatives consistent with their profiles. Nonetheless, Rifon et al. (2004) indicate that important elements of the schema and associative learning theories remain unclear. The study of what motivates an organisation to engage in CSR activities can bring greater clarity to these approaches. Motivational attributions are the result of cognitive processes by which customers assign causes to observed situations. Following the virtue ethics perspective, van de Ven (2008) suggests that CSR initiatives can only be considered virtuous if they satisfy an altruistic motivation of a company rather than egoistic interests. Thus, only the attribution of altruistic motivations generates positive responses from customers. 
According to these ideas, there is a need for scholars to consider both C-CSR congruence and motivational attribution together, thus providing greater explanatory power for models designed to explain the processes of CSR perception formation. There exists the possibility that C-CSR congruence has a direct effect on motivational attribution (Rifon et al., 2004; Becker-Olsen et al., 2006; Ellen et al., 2006). Following the ideas proposed by the schema and associative learning theories, Rifon et al. (2004) empirically confirm that C-CSR congruence positively influences customer perceptions of altruistic corporate motivations. Ellen et al. (2006) also suggest that a greater compatibility between the goals of a CSR initiative and the core business of a company can make the allocation of strategic, value-based motivations more feasible, while simultaneously decreasing the chance of perceptions of egoistic corporate motivations. Based on these ideas, the first research hypothesis is as follows:

\section{H1: C-CSR congruence directly and positively influences the motivations attributed to a company in the development of its CSR initiatives.}

Furthermore, C-CSR congruence can influence corporate credibility. In this regard, credibility refers to the degree to which customers, investors and other constituents believe in corporate expertise and trustworthiness when companies develop CSR initiatives (Goldsmith et al., 2000). One can argue that if customers perceive that CSR initiatives are consistent with corporate profile, they will be perceived as credible because the company-CSR link is easily understood and integrated into their mental schemas. In contrast, if CSR initiatives are not consistent with the identity the company is trying to convey, the effort customers have to devote to understanding CSR will reduce corporate credibility (Bigné et al., 2009). 
Along these lines, attribution theory (Folkes, 1988) describes customers as rational information processors whose behaviour is influenced by the causal inferences they make about events they observe and experience. In terms of CSR, the theory proposes that altruistic motivations can form the basis of corporate credibility and influence customer attitudes towards companies. Rifon et al. (2004) show that the more altruistic motivations customers perceive in companies engaging in CSR, the greater their evaluation of corporate credibility. Similarly, Becker-Olsen et al. (2006) demonstrate that the allocation of altruistic motivations may counteract the negative effect of low CCSR congruence by positively impacting on corporate credibility. Based on these ideas, two new research hypotheses propose that:

\section{H2: C-CSR congruence directly and positively influences corporate credibility.}

\section{H3: The motivations attributed to a company in the development of its CSR initiatives directly and positively influence its corporate credibility.}

It is also noted that corporate credibility is an essential factor in building brand value through CSR (Hoeffler and Keller, 2002). Following this line of thought, recent literature points to the significant role played by companies (as sources of messages) in determining customer responses to business strategies and communication processes (Kim and Choi, 2007). The persuasion (Hovland et al., 1953), cognitive response (Greenwald, 1968) and reasoned action (Fishbein and Ajzen, 1975) theories propose that an expert and reliable source of information is more persuasive than a source perceived as less reliable (Lafferty and Goldsmith, 1999). For example, Lafferty and 
Goldsmith (1999) confirm that higher levels of corporate credibility cause customers to construct positive attitudes towards companies. Similarly, Goldsmith et al. (2000) confirm that customers exposed to an advertisement from a highly credible company develop more positive attitudes toward the brand. In the CSR field, Hoeffler and Keller (2002) state that brand credibility is a necessary antecedent to building brand value through social marketing. The theoretical and empirical evidence provided by these studies allows the present authors to suggest the following hypothesis:

\section{H4: Corporate credibility directly and positively influences CSR perceptions.}

For the following hypotheses, the authors also drew on associative learning and attribution theories. The associative learning theory assumes that high C-CSR congruence improves customer attitudes toward companies because it leads them to believe that corporate behaviour is satisfactory (Till and Nowak, 2000). Therefore, a good fit between a company and its CSR initiatives will be more easily integrated into customer associative networks, strengthening perceptions of a positive relationship between a company and its CSR initiatives (Fiske and Taylor, 2008). In turn, C-CSR congruence strengthens the market position of a company, which is important in helping customers understand the acceptability of a company within its competitive environment, while also providing brand differentiation, reducing uncertainty and increasing purchase intentions (Becker-Olsen et al., 2006).

Furthermore, Barone et al. (2000) demonstrate that customers have positive perceptions of brands that show altruistic motivations in the support of CSR initiatives. For some CSR initiatives, however, companies might be perceived as the main beneficiaries and, 
therefore, exploitative. Becker-Olsen et al. (2006) show that when a company's operations are guided by egoistic motivations, their CSR initiatives generate a greater number of unfavourable perceptions in the minds of customers. These thoughts lead customers to question corporate motivations, and these negative attributions ultimately reduce purchase intentions. The opposite occurs when customers perceive altruistic corporate motivations. In line with these ideas, two new research hypotheses propose that:

H5: C-CSR congruence directly and positively influences CSR perceptions.

H6: The motivations attributed to a company in the development of its CSR initiatives directly and positively influence CSR perceptions.

\subsection{Novelty seeking and its influence on the process of customer CSR perception} formation

Concerning the second research goal of the paper, one of the greatest limitations of previous literature on the topic is that scholars have traditionally ignored that possible moderating effects exist in the process of customer CSR perception formation and, thus, they have not analysed the usefulness of market segmentation in this context. Market segmentation involves grouping customers so that: 1) those in one segment share common characteristics, purchasing behaviour or needs which are reasonably homogeneous; while 2) customers allocated to a separate market segment share a different set of such traits and behaviours (Simkin, 2008). According to Hunt and Arnett (2004) the purpose of market segmentation is to achieve competitive advantage. For this 
purpose, companies should: 1) identify segments of demand; 2) target specific segments; and 3) develop specific marketing 'mixes' for each targeted market segment (Hunt and Arnett, 2004).

Scholars have widely proved the effectiveness of market segmentation when companies design their commercial offerings and plan their communication strategies (Simkin, 2008). However, researchers have as yet not extended their analyses to determine how companies can develop more effective CSR initiatives based on customer market segmentation. In this paper, the authors are interested in evaluating the effectiveness of novelty seeking for market segmentation regarding CSR by describing the process of CSR perception formation among conservative and innovative customers. In this regard, the authors believe that the current 'unconsolidated' state of CSR in Spain might influence the process of CSR perception formation among customers in this country.

CSR is a relatively new management tool for businesses in Spain (Melé, 2004). Companies have only recently begun to use it regularly, specifically since the creation of the United Nations' Global Compact in 1999; the publication of the Green Paper for the promotion of a European framework for Corporate Social Responsibility in 2001; and the development of several stock market sustainability indexes - e.g. FTSE4Good and public opinion rankings - e.g. MORI (Argandoña, 1999; Melé, 2004). In this regard, Melé (2004) considers that in Spain, as in other countries, there have been two 'waves' of Corporate Social Responsibility (CSR). The first - weaker - one was in the 1970s, and the second at the beginning of the 21 st century, since when there has been renewed interest in CSR throughout Europe and worldwide. The Spanish government launched its first public CSR initiative in 2005 (Libro Blanco sobre RSC, Ministerio de 
Trabajo y Asuntos Sociales, see Table 1). Up to that date, only a few private foundations had addressed this issue, albeit poorly.

\section{Insert Table 1 here}

The novelty of the concept is even clearer in the context of the Spanish banking industry, where the present authors implemented the current study. Salient companies in the Spanish banking industry, such as the Santander Group or BBVA, have only recently started to implement CSR policies. Santander Group, for example, first designed a strategic plan including CSR concerns in 2002. Also in 2002, BBVA launched its first comprehensive CSR program (see Table 1). Based on this fact, the authors of this paper consider that the novelty of CSR initiatives in the Spanish banking industry might influence the way in which customers form CSR perceptions because only innovative customers will make efforts to process CSR information and include it in their perceptions of companies.

To justify this proposal, the authors first draw on innovation diffusion theory (Rogers, 1995). According to this approach, not all customers respond equally to an innovation introduced into a market. There are customers more prone to accepting innovations (innovative customers), while others are more reluctant (conservative customers) (Venkatraman and Price, 1990). Rogers (1995) supports the idea that the diffusion of an innovation in the market occurs as a consequence of a communication process, where customers receive information about new products or technologies through two types of communicational channels: mass media and interpersonal communication. As a result, the most innovative customers base their decision to accept a new product or concept on 
the information they receive from immediate mass media. The least innovative customers also need positive interpersonal communication to reinforce their behaviour, a requirement which takes time since more people are needed to test the innovation. Therefore, pioneers react as leaders of opinion and as the number of customers who adopt an innovation grows, the level of social influence on others who have yet to adopt the innovation also grows (Rogers, 1995).

Innovation diffusion theory is also consistent with the traditional model of product life cycle (Wasson, 1978), broadly accepted in marketing literature to delimit the stages of innovation acceptance (Lamb et al., 2005). According to this model, competition, information processing and consumption behaviours vary as the use of an innovation spreads. Thus, in the introductory phase the product/concept is only accepted by innovators. The early adopters and an early majority join the market during the growing phase. Finally, customers who constitute the late majority and the laggards accept the product/concept only during stages of maturity and decline.

Furthermore, it is well known that when customers are highly involved in something, they evaluate it more critically than other customers because the possibility of being manipulated or deceived would be perceived as a threat to their own self-identity (Bigné et al., 2009). Thus, highly-involved customers need to protect their self-esteem and personal identity and as such are stricter in their assessment of the things they are involved in (Bigné et al., 2009). This assessment is commonly based on additional facts and information that non-involved customers do not usually take into consideration (Menon and Kahn, 2003). Based on this reasoning, it is proposed that innovative customers, who are highly involved with new concepts, strategies and products in the 
marketplace, dedicate greater effort to informing themselves about CSR. In order to be consistent with their beliefs, innovative customers need to base their perceptions on reliable reviews of CSR and its determining variables. On the contrary, customers less interested in novelties are not as likely to perceive CSR as a threat to their concept of self, thus they do not need to legitimate CSR initiatives or evaluate them using as many heuristics when forming CSR perceptions (Bigné et al., 2009). They show trust in more accessible indicators regarding the behaviour of companies which has a halo effect when judging CSR. They also shape a less thought-intensive CSR perception, taking fewer CSR dimensions into consideration.

Finally, it is also known that conservative customers are risk averse (Schiffman and Kanuk, 2009). This fact is especially significant in reference to the recent global financial crisis and might influence both information processing and relationship behaviour. In the face of a crisis, conservative customers tend to base their decisions on traditional, stable, secure and widely-accepted economic metrics which demonstrate the reliability of their (e.g. banking) service providers. CSR is, however, a nascent domain which also raises society's scepticism because it is considered a utilitarian strategy to recover corporate credibility and reputation quickly (Morsing and Schultz, 2006; Pomering and Johnson, 2009). Thus, this is a risky concept which raises the suspicion of conservative customers, which they may not take into consideration when making their buying decisions. According to this idea, information processing in regard to CSR may be less thought-intensive among conservative customers because they are not interested in evaluating CSR as part of their relationship with (e.g. banking) institutions. 
These ideas allow the authors to propose the final research hypothesis (and subhypotheses) of the paper, aimed at analysing the moderating effect of novelty seeking in the causal model described to understand customer CSR perceptions:

H7: Novelty seeking moderates the process of CSR perception formation.

H7a: The influence of $\mathrm{C}$-CSR congruence on motivational attribution is greater among innovative customers than conservative customers.

H7b: The influence of $\mathrm{C}$-CSR congruence on corporate credibility is greater among innovative customers than conservative customers.

H7c: The influence of C-CSR congruence on CSR perceptions is greater among innovative customers than conservative customers.

H7d: The influence of motivational attribution on corporate credibility is greater among innovative customers than conservative customers.

H7e: The influence of motivational attribution on CSR perceptions is greater among innovative customers than conservative customers.

H7f: The influence of corporate credibility on CSR perceptions is greater among innovative customers than conservative customers.

Figure 1 represents the conceptual model tested in this paper, along with the expected moderating effect of novelty seeking.

Insert Figure 1 here 


\section{RESEARCH DESIGN}

To test the hypotheses, a study based on personal surveys of banking services customers in Spain was conducted. The banking industry was selected as the context for the development of the research because of two reasons: 1) as explained in the literature review in this paper, CSR is still a relatively new concept in the Spanish banking industry and, as such, differences in CSR perceptions can be anticipated when customers show different interest in innovation; 2) when compared with other industries, banking institutions tend to have greater visibility in the community since they play a significant role in daily customer routine (Mandell et al., 1981). This fact allows the consideration that banking industry CSR initiatives are more likely to be familiar to customers. Thus, customers are in a better position to evaluate the CSR initiatives of banking providers than to evaluate other companies.

\subsection{Measurement scales}

Seven-point Likert-type scales (1=strongly disagree with the sentence, $7=$ strongly agree) were used to measure all the concepts in the model (see Appendix). First, a fouritem scale, based on previous proposals by Lafferty et al. (2004) and Bigné et al. (2009), was developed to measure C-CSR congruence, which referred to the similarities between CSR initiatives and corporate profiles. The scale is aligned with the ideas of previous scholars who considered that companies must create a symbolic link with their CSR partners, based on similarities in their images and positioning (Bigné et al., 2009). Motivational attribution was measured by means of a four-item scale oriented toward identifying customer perceptions of the egoistic or altruistic nature of companies in 
developing their CSR initiatives. When egoistic motivations are perceived by customers, these stakeholders consider that the main beneficiaries of CSR initiatives are businesses themselves. On the contrary, if altruistic motivations are perceived, customers consider that the main beneficiary of CSR initiatives is society (Bigné et al., 2009). In designing the scale, the works of Becker-Olsen et al. (2006) and Bigné et al. (2009) were taken as references. Corporate credibility was measured using the proposal made by Newell and Goldsmith (2001). Thus, a four-item scale was used where two items measured corporate trustworthiness and two items measured corporate expertise in CSR. Corporate trustworthiness refers to the confidence offered by the company (e.g. the company is perceived as an organisation "you can rely on"; Ohanian, 1990). Expertise indicates the degree of skill and competence demonstrated by a company in the production and distribution of its products and services (MacKenzie and Lutz, 1989). CSR perceptions were measured using a stakeholder-based scale proposed by Pérez et al. (2013). The scale was composed of 22 items gathered in five dimensions customers; shareholders and supervising boards; employees; society; and a general dimension concerning legal and ethical issues which included corporate responsibilities towards a broad array of stakeholders. The scale was based on stakeholder theory, which has been demonstrated to perfectly fit the banking industry approach to CSR (Pérez and Rodríguez del Bosque, 2012). A detailed explanation of the development of the scale can be found in Pérez et al. (2013). Finally, novelty seeking was measured by means of a four-item scale which evaluated customer stimulation and self-direction, that is, customer preference for having an exciting life, engaging in stimulating activities and trying new things (Fraj and Martínez, 2006). This scale was based on the ideas of Schwartz (1992), who developed a universal value structure grouped into four dimensions: self-transcendence (universalism, benevolence); self-enhancement (power, 
achievement); openness (self-direction and stimulation); and tradition (conformity, security). Fraj and Martínez (2006) also tested the validity of this proposal and confirmed that novelty seeking (openness, according to Schwartz, and adventurousness in spirit, according to Fraj and Martínez) was composed of the two dimensions of stimulation and self-direction.

\subsection{Sample profile and segmentation}

A non-probabilistic sampling procedure was used to select respondents to the survey. Respondents were customers of banking services over 18 years of age who lived in a certain medium-sized region in Spain (withheld due to anonymity). Banking service customers were people who had at least one bank account for which they were the main decision makers. These customers represent $91.6 \%$ of the population in Spain. With the purpose of guaranteeing a more accurate representation of the data, a multi-stage sampling by quotas was used based on customer gender and age.

After the collection and processing of information, a total of 1,124 valid surveys remained (response rate $=93.7 \%$ ). The global sample was $48.5 \%$ male and $51.5 \%$ female, which is comparable with demographic information for the entire country according to Instituto Nacional de Estadística data up to 1 January 2009 (49\% female and $51 \%$ male). Regarding age, $46.6 \%$ customers in the sample were under 44 years of age $(50.1 \%$ in the national population rate), $31.7 \%$ between 45 and $64(29.7 \%$ in the national population rate) and $21.7 \%$ over 64 years of age $(20.2 \%$ in the national population rate). 
This global sample was also segmented according to novelty seeking. Customers were assigned either a low (conservative) or high (innovative) category depending on the strength of the manifestation of this characteristic in their value structure. Conservative customers represented $41 \%$ of the population in the sample while innovative customers represented 59\%. Regarding the characterisation of both customer categories, innovative customers were younger (mostly under 44 years of age), highly educated (46.2\% of customers had a college degree), generally single (45.6\%) and full-time workers $(45.8 \%)$ with a high income. On the other hand, conservative customers were older (mostly over 45 years of age), with a lower level of education $(74.5 \%$ of customers had an educational level below tertiary study) and were generally married $(58.3 \%)$. They were full-time workers $(33.3 \%)$, homemakers $(11.6 \%)$ or retired customers $(32.5 \%)$ with slightly lower salaries than innovative customers. Table 2 shows the most significant demographic variables defining each customer category.

\section{Insert Table 2 here}

\subsection{Method}

First, hypotheses H1-H6, which refer to the relationships among C-CSR congruence, motivational attribution, corporate credibility and CSR perceptions, were tested through a structural equation model implemented with the statistical software EQS 6.1. For this purpose, the global sample was analysed.

Second, a multisampling structural equation analysis was performed to test the subhypotheses of $\mathrm{H} 7$, namely $\mathrm{H} 7 \mathrm{a}-\mathrm{H} 7 \mathrm{f}$. For this purpose, a three-step process was 
developed to estimate the causal model in each subsample (conservative and innovative customers) and compare the results between them. The multisampling analysis was performed and a multi-group solution of causal relationships was obtained to understand the process of CSR perception formation among customers. The purpose of this first step was to determine the standardised coefficients of the six relationships in each model subsample. Another step consisted of testing the factorial invariance of the structural equation model between customer categories. The purpose of this step was to ensure that the latent constructs (C-CSR congruence, motivational attribution, corporate credibility and CSR perceptions) were understood in the same way among customers with different orientations toward novelty seeking; thus the model was comparable among them. The factorial invariance was studied through the Lagrange Multiplier (LM) test, which allowed the authors to compare chi-square differences of the relationships when the restriction concerning equality among the factorial lambdas in both customer categories was eliminated. When the results of this analysis showed nonsignificant values in the improvement of the chi-square $(p>0.05$ for a $95 \%$ confidence level), the factorial invariance was confirmed. The final step of the analysis consisted of estimating the structural invariance of the model between customer categories. This property was evaluated by recalculating the causal model including the restriction that the standardised betas of the relationships between all the latent constructs had to be equal between customer categories. Again, the suitability of this restriction was tested with the LM test. This time, it was necessary for the chi-square differences to be significant $(\mathrm{p}<0.05$ for $95 \%$ confidence) to confirm that novelty seeking was a moderator of the relationship under scrutiny. 


\section{FINDINGS}

\subsection{Findings regarding the relationships among C-CSR congruence, motivational attribution, corporate credibility and CSR perceptions}

\subsubsection{Validation of the measurement scales}

Before proceeding to the analysis of the hypotheses, the reliability, validity and goodness of fit of the scales were globally tested to ensure that the model fitted to the data properly. For this purpose, the authors implemented a first-order confirmatory factor analysis (CFA) with all the latent constructs and taking into consideration the global sample in the study. The results of the CFA are presented in Table 3. Although the Satorra-Bentler $\chi^{2}$ was significant $(\mathrm{S}-\mathrm{B} \chi 2=568.68$, $\mathrm{p}$-value $<0.05)$, because of the large sample used in the analysis (over 200 cases), all the Comparative Fit Indexes NFI, NNFI, CFI and IFI - exceeded the minimum recommended value of 0.90 , demonstrating an adequate fit of the model. In addition, the standardised lambdas obtained for C-CSR congruence, motivational attribution, corporate credibility and CSR perceptions were significant and greater than 0.50 , ensuring the convergent validity of the model. Finally, the authors evaluated the discriminant validity of the factorial structure, estimating the confidence intervals for the correlation between pairs of constructs. The results verified the discriminant validity of the model because no confidence interval included the digit one.

\section{Insert Table 3 here}




\subsubsection{Hypotheses testing}

Once the validity of the measurement scales was successfully tested, the estimation of the causal relationships in Figure 1 was performed. Table 4 shows the results of the analysis. Again, the Comparative Fit Indexes were above 0.90, showing an adequate fit of the model. The results also confirmed the proposed relationships among C-CSR congruence, motivational attribution and corporate credibility. Firstly, there was a significant relationship between C-CSR congruence and motivational attribution $(\beta=0.27, \mathrm{p}<0.05)$, on the one hand, and corporate credibility $(\beta=0.44, \mathrm{p}<0.05)$, on the other; therefore $\mathrm{H} 1$ and $\mathrm{H} 2$ are supported. Furthermore, there was a significant relationship between motivational attribution and corporate credibility $(\beta=0.46, \mathrm{p}<0.05)$. Therefore, H3 is also supported. Regarding the relationships of these concepts with CSR perceptions, the results showed the value of companies inspiring credibility when developing their CSR initiatives because this allowed them to further improve customer CSR perceptions $(\beta=0.29, \mathrm{p}<0.05)$. Consequently, H4 is supported. Furthermore, $\mathrm{C}$ CSR congruence directly contributed to the generation of CSR perceptions $(\beta=0.21$, $\mathrm{p}<0.05)$ so $\mathrm{H} 5$ is also supported. Finally, the attribution of altruistic or egoistic motivations automatically determined CSR perceptions $(\beta=0.23, p<0.05)$, such that H6 is supported.

\section{Insert Table 4 here}




\subsection{Findings regarding the moderating role of novelty seeking in the process of CSR perception formation}

\subsubsection{Hypotheses testing}

Regarding the results of the multisampling analysis, first the factorial invariance of the model was confirmed ( $p>0.05$ in $100 \%$ of the lambdas compared). Then it was demonstrated that the model was appropriate to understand the formation process of CSR perceptions among the two different types of customers independently consulted (conservative vs. innovative customers). Thus, the authors proceeded to test $\mathrm{H} 7 \mathrm{a}-\mathrm{H} 7 \mathrm{f}$.

Table 5 presents the results of the multisampling analysis implemented to determine novelty seeking. Findings concerning the models in each customer category, the LM test of the structural invariance and the goodness of fit of the final model (with model restrictions eliminated) are also included in Table 5. Based on the significance of the chi-square differences included in Table 5, the results show that novelty seeking (Dif. $\left.\chi^{2}=15.50, \mathrm{p}<0.05\right)$ moderated the process of CSR perception formation.

\section{Insert Table 5 here}

Specifically, customers with diverse orientations towards novelty seeking exhibited significant differences regarding the impact that C-CSR congruence had on CSR perceptions $\left(\beta_{\text {conservative }}=0.30, \mathrm{p}<0.05\right.$ vs. $\beta_{\text {innovative }}=0.21, \mathrm{p}<0.05$; Dif. $\left.\chi 2=3.50, \mathrm{p}<0.1\right)$, in the effect of motivational attribution on corporate credibility $\left(\beta_{\text {conservative }}=0.42, \mathrm{p}<0.05\right.$ vs. $\beta_{\text {innovative }}=0.55, \mathrm{p}<0.05$; Dif. $\left.\chi 2=3.32, \mathrm{p}<0.1\right)$ and CSR perceptions $\left(\beta_{\text {conservative }}=0.27\right.$, 
$\mathrm{p}<0.05$ vs. $\beta_{\text {innovative }}=0.15, \mathrm{p}<0.05$; Dif. $\left.\chi^{2}=8.02, \mathrm{p}<0.05\right)$ and in the impact of corporate credibility on CSR perceptions $\left(\beta_{\text {conservative }}=0.14, p>0.05\right.$ vs. $\beta_{\text {innovative }}=0.42, p<0.05$; Dif. $\chi^{2}=$ n.a.). Significant differences were not observed in the effect of C-CSR congruence on either motivational attribution $\left(\beta_{\text {conservative }}=0.32, p<0.05\right.$ vs. $\beta_{\text {innovative }}=0.18, p<0.05$; Dif. $\left.\chi^{2}=1.61, \quad \mathrm{p}>0.05\right)$ or corporate credibility $\left(\beta_{\text {conservative }}=0.45, \quad \mathrm{p}<0.05 \quad\right.$ vs. $\beta_{\text {innovative }}=0.34, \mathrm{p}<0.05$; Dif. $\left.\chi 2=0.69, \mathrm{p}>0.05\right)$. These results allow the authors to accept H7 partially. The sub-hypotheses $\mathrm{H} 7 \mathrm{~d}$ and $\mathrm{H} 7 \mathrm{f}$ are accepted while sub-hypotheses $\mathrm{H} 7 \mathrm{a}-$ $\mathrm{H} 7 \mathrm{c}$ and H7e are not accepted.

\section{DISCUSSION}

The purpose of this empirical research was to clarify the process that leads customers to form CSR perceptions of businesses in the banking industry. Some research had been devoted to analysing this process (Rifon et al., 2004; Ellen et al., 2006; Becker-Olsen et al., 2006; Bigné et al., 2009) but new information regarding the way psychological characteristics influence customer CSR perceptions was needed. In this regard, this paper contributes to academic literature in the field by including the analysis of the moderating role of novelty seeking in studying the process of CSR perception formation.

The findings of the paper confirm the adequacy of the model proposed by the authors to understand the process of CSR perception formation among innovative customers. These customers' CSR perceptions are based on three variables: the congruence between CSR initiatives and corporate profile; the attribution of motivations for a company to implement CSR; and corporate credibility in developing CSR initiatives. 
First, there is a direct relationship between the corporate motivations perceived by customers and corporate credibility. In this manner, and in accordance with the proposals of attribution theory (Folkes, 1988), the current study shows that when customers perceive that companies have altruistic motivations when designing and implementing CSR initiatives they are more credible and customers form more positive CSR perceptions. In contrast, companies lose credibility when they are perceived as egoistic, such as when customers anticipate intrinsic motivations for carrying out CSR initiatives and believe that CSR seeks not the public benefit of stakeholders but the private benefit of companies. The loss of credibility contributes to the deterioration of CSR perceptions which can have direct consequences on corporate reputation as well as on customer satisfaction, retention or company identification. As a key element to facilitate the attribution of altruistic motivations and to improve the credibility of CSR initiatives, it is essential that corporate profile and CSR initiatives are congruent. When it makes sense to customers that their banking institutions perform CSR, they have better perceptions of corporate motivations and credibility. Therefore, CSR initiatives which are consistent with corporate goals will help in improving customer CSR perceptions. This proposal confirms associative learning theories, which argue that associations with CSR can transfer meaning onto organisations (Lynch and Schuler, 1994; Till and Nowak, 2000). All in all, these findings of the paper confirm the integrative proposal of Rifon et al. (2004) as well as its partial replications in service industries (i.e., Ellen et al., 2006; Becker-Olsen et al., 2006; Bigné et al., 2009).

Conversely, relationships among C-CSR congruence, motivational attribution, credibility and CSR perceptions are not fully accepted by conservative customers; thus the authors' intuition that these customers elaborate less thought-intensive CSR 
perceptions than innovative customers is confirmed and supports the proposals of previous theories such as the innovation diffusion theory (Rogers, 1995) and the model of product life cycle (Wasson, 1978). These theoretical approaches consider that customers less interested in novelties are not as likely to perceive CSR as a threat to their concept of self and thus they do not need to evaluate them using as many heuristics as innovative customers when forming CSR perceptions (Bigné et al., 2009). Conservative customers only evaluate C-CSR congruence and motivational attribution when forming CSR perceptions, whereas credibility is irrelevant for them.

Nonetheless, some of the results are surprising because they contradict some prior expectations. For example, it was observed that, contrary to the authors' proposal, CCSR congruence and motivational attribution are more relevant for conservative customers than innovative customers when forming CSR perceptions. The authors believe these results are closely connected to the context where the research was developed. In this regard, since 2007, the Spanish banking industry has faced a loss in trust because of frequent financial scandals and poor corporate governance practices. Furthermore, over the past decade most banking institutions have diverted their attention towards activities scarcely related to their business and expertise scopes, such as building societies massively investing in the real estate sector (Pérez and Rodríguez del Bosque, 2012). Thus, it makes sense that conservative customers are not willing to take risks when evaluating CSR and only rely on two concepts, which were the weaknesses of banking institutions during the recent financial crisis: C-CSR congruence and motivational attribution. Innovative customers follow a more comprehensive approach and attribute greater value to whether companies show expertise and are trustworthy when implementing CSR initiatives. 


\section{CONCLUSIONS}

The findings in this paper can allow managers to design personalised relationships with diverse types of customers depending on their value schemas and CSR perceptions. These results have important implications for companies which face the need to adapt their CSR and communication strategies in an adequate manner to address the different processes of customer CSR perception formation. In line with the propositions of relationship marketing theory, personalising CSR and communication strategies will improve efficiency and the positive outcomes of CSR initiatives, such as customer satisfaction and loyalty. In this regard, the role of C-CSR congruence, motivational attribution and corporate credibility on CSR perceptions must be clarified based on the customer categories analysed in this paper. It has been observed that innovative customers organise their CSR perceptions mostly around corporate credibility (expertise and trustworthiness) while conservative customers attribute more importance to C-CSR congruence and motivational attribution. These ideas must be reflected in the way banking institutions relate to their customers.

Specifically, the authors suggest companies should target their CSR communications to innovative customers. Companies should orient their CSR communications towards the projection of a credible connection between the company and its CSR initiatives. Conversely, when establishing a relationship with conservative customers, companies should better focus on highlighting the traditional features of their brands and products such as, for example, price or quality: scholars have demonstrated that conservative 
customers are risk-averse and prefer basing their decisions on traditional, stable, secure and widely-accepted economic metrics.

\section{LIMITATIONS AND FUTURE LINES OF RESEARCH}

Some limitations of this paper must be admitted to. In this regard, the fact that data was gathered from customers in a single country can limit the generalisability of the findings to other research contexts. Also, the fact that the authors did not control for the influence of diverse information sources on customer perceptions makes it necessary for readers to interpret the findings with caution. Another significant limitation of the research was the fact that the data was collected during the international economic crisis and thus results might have been affected by this situation.

Future scholars should implement longitudinal studies because they will allow researchers to test the value of novelty seeking as a moderator in different phases of the economic cycle. The special relevance of novelty seeking when explaining differences in the processes of customer CSR perception formation brings into consideration the possibility that significant moderating effects also exist for other cognitive and emotional customer responses to CSR perceptions. The authors have not gone this far in the study, thus scholars could concentrate on providing new insights in this regard. More comparative studies are also needed along this path of research.

The authors also believe that some inter-correlations may have occurred in the characterisation of conservative and innovative customers. For example, innovative customers are younger, better educated and better paid than conservative customers. 
However, it was not the purpose of the present authors to identify these connections; future research in this area could be interesting indeed.

\section{REFERENCES}

Argandoña, A. (1999), "Business Ethics in Spain”, Journal of Business Ethics, Vol. 22 No. 3, pp. 155-173.

Barone, M.J., Miyazaki, A.D. and Taylor, K.A. (2000), "The influence of cause-related marketing on consumer choice: Does one good turn deserve another?", Journal of the Academy of Marketing Science, Vol. 28 No. 2, pp. 248-262.

Becker-Olsen, K.L., Cudmore, B.A. and Hill, R.P. (2006), "The impact of perceived corporate social responsibility on consumer behaviour", Journal of Business Research, Vol. 59 No. 1, pp. 46-53.

Bigné, E., Currás, R. and Sánchez, I. (2009), "Brand credibility in cause-related marketing: The moderating role of consumer values", The Journal of Product and Brand Management, Vol. 18 No. 6, pp. 437-447.

Brown, T.J. and Dacin, P.A. (1997), "The company and the product: Corporate associations and consumer product responses", Journal of Marketing, Vol. 61, pp. 6884.

Ellen, P.S., Webb, D.J. and Mohr, L.A. (2006), "Building corporate associations: Consumer attributions for corporate socially responsible programs", Journal of the Academy of Marketing Science, Vol. 34 No. 2, pp. 147-157.

Fishbein, M. and Ajzen, I. (1975), Belief, Attitude, Intention and Behaviour. An Introduction to Theory and Research, Addison-Wesley, Reading. 
Fiske, S.T. and Taylor, S.E. (2008), Social Cognition: From Brains to Culture. McGraw-Hill, Boston, MA.

Folkes, V.S. (1988), "Recent attribution research in consumer behaviour: A review and new directions", Journal of Consumer Research, Vol. 14 No. 4, pp. 548-565.

Fraj, E. and Martínez, E. (2006), "Environmental values and lifestyles as determining factors of ecological consumer behaviour: An empirical analysis", The Journal of Consumer Marketing, Vol. 23 No. 3, pp. 133-144.

Fukukawa, K., Balmer, J.M.T. and Gray, E.R. (2007), "Mapping the interface between corporate identity, ethics and corporate social responsibility". Journal of Business Ethics, Vol. 76 No. 1, pp. 1-5.

García de los Salmones, M.M., Herrero, Á. and Rodríguez del Bosque, I. (2005), "Influence of corporate social responsibility on loyalty and valuation of services", Journal of Business Ethics, Vol. 61 No. 4, pp. 369-385.

García de los Salmones, M.M., Pérez, A. and Rodríguez del Bosque, I. (2009), "The social role of financial companies as determinants of consumer behaviour", International Journal of Bank Marketing, Vol. 27 No. 6, pp. 467-485.

Garriga, E. and Melé, D. (2004), "Corporate social responsibility theories: Mapping the territory", Journal of Business Ethics, Vol. 53 No. 1-2, pp. 51-71.

Goldsmith, R.E., Lafferty, B.A. and Newell, S.J. (2000), “The impact of corporate credibility and celebrity credibility on consumer reaction to advertisements and brands", Journal of Advertising, Vol. 29 No. 3, pp. 43-54.

Hoeffler, S. and Keller, K.L. (2002), "Building brand equity through corporate societal marketing”, Journal of Public Policy and Marketing, Vol. 21 No. 1, pp. 78-89.

Hovland, C., Janis, I. and Kelley, H. (1953). Communication and Persuasion. Psychological Studies of Opinion Change, Yale University Press, New Haven, CT. 
Hunt, S.D. and Arnett, D.B. (2004), "Market segmentation strategy, competitive advantage, and public policy: Grounding segmentation strategy in resource-advantage theory", Australasian Journal of Marketing, Vol. 12 No. 1, pp. 7-25.

Jenkins, H. (2006), "Small business champions for corporate social responsibility", Journal of Business Ethics, Vol. 67, pp. 241-256.

Kim, K. and Choi, S. (2007), "Understanding the impacts of sponsorship. Induced beliefs on corporate credibility and attitude toward the sponsor", in American Academy of Advertising Conference Proceedings.

Lafferty, B.A. and Goldsmith, R.E. (1999), “Corporate credibility's role in consumers' attitudes and purchase intentions when a high versus a low credibility endorser is used in the ad", Journal of Business Research, Vol. 44 No. 2, pp. 109-116.

Lafferty, B.A., Goldsmith, R.E. and Hult, G.T.M. (2004), "The impact of the alliance on the partners: A look at cause-brand alliances", Psychology and Marketing, Vol. 21 No. 7, pp. 509-531.

Lai, C.S., Chiu, C.J., Yang, C.F. and Pai, D.C. (2010), “The effects of corporate social responsibility on brand performance: The mediating effect of industrial brand equity and corporate reputation”, Journal of Business Ethics, Vol. 95 No. 3, pp. 457-469.

Lamb, C.W., Hair, J.F. and McDaniel, C. (2005), Essentials of Marketing: 4th edition, South-Western, Cincinnati, $\mathrm{OH}$.

Lynch, J. and Schuler, D. (1994), “The match up effect of spokesperson and product congruency: A schema theory interpretation”, Psychology and Marketing, Vol. 11 No. 5, pp. 417-445.

MacKenzie, S.B. and Lutz, R.J. (1989), “An empirical examination of the structural antecedents of attitude toward the ad in an advertising pretesting context", Journal of Marketing, Vol. 53 No. 2, pp. 48-65. 
Maignan, I. and Ferrell, O.C. (2001), “Corporate citizenship as a marketing instrument - Concepts, evidence and research directions", European Journal of Marketing, Vol. 35 No. 3-4, pp. 457-484.

Mandell, L., Lachman, R. and Orgler, Y. (1981), "Interpreting the image of banking", Journal of Bank Research, Vol. 12 No. 2, pp. 96-104.

Matute, J., Bravo, R. and Pina, J.M. (2010), "The influence of corporate social responsibility and price fairness on customer behaviour: Evidence from the financial sector", Corporate Social Responsibility and Environmental Management, Vol. 18 No. 6, pp. 317-331.

McDonald, H. and Alpert, F. (2007), "Who are "innovators" and do they matter? A critical review of the evidence supporting the targeting of "innovative" consumers", Marketing Intelligence \& Planning, Vol. 25 No. 5, pp. 421-435.

Melé, D. (2004), Corporate social responsibility in Spain: An overview, in working paper, IESE Business School, Universidad de Navarra.

Menon, S. and Kahn, B.E. (2003), “Corporate sponsorships of philanthropic activities: When do they impact perception of sponsor brand?", Journal of Consumer Psychology, Vol. 13 No. 3, pp. 316-327.

Morsing, M. and Schultz, M. (2006), “Corporate social responsibility communication: Stakeholder information, response and involvement strategies", Business Ethics: A European Review, Vol. 15 No. 4, pp. 323-338.

Newell, S.J. and Goldsmith, R.E. (2001), "The development of a scale to measure perceived corporate credibility", Journal of Business Research, Vol. 52 No. 3, pp. 235247. 
Ohanian, R. (1990), “Construction and validation of a scale to measure celebrity endorsers' perceived expertise, trustworthiness, and attractiveness", Journal of Advertising, Vol. 19 No. 3, pp. 39-52.

Pérez, A. and Rodríguez del Bosque, I. (2012), "Corporate social responsibility as a new important dimension of corporate identity", Journal of Business Ethics, Vol. 108, pp. 145-166.

Pérez, A. and Rodríguez del Bosque (2013), "Measuring CSR image: Three studies to develop and to validate a reliable measurement tool", Journal of Business Ethics, Vol. 118 No. 2, pp. 265-286.

Pérez, A., Martínez, P. and Rodríguez del Bosque, I. (2013), "The development of a stakeholder-based scale for measuring corporate social responsibility in the banking industry”, Service Business, Vol. 7 No. 3, pp. 459-481.

Pomering, A. and Johnson, L.W. (2009), “Advertising corporate social responsibility initiatives to communicate corporate image", Corporate Communications, Vol. 14 No. 4, pp. 420-439.

Rifon, N.J., Choi, S.M., Trimble, C.S. and Li, H. (2004), "Congruence effects in sponsorship: The mediating role of sponsor credibility and consumer attributions of sponsor motive", Journal of Advertising, Vol. 33 No. 1, pp. 29-42.

Rogers, E.M. (1995), Diffusion of Innovations: $4^{\text {th }}$ edition, Free Press, New York, NY. Schiffman, L.G. and Kanuk, L.L. (2009), Consumer Behavior, Prentice-Hall, Boston, MA.

Schwartz, S.H. (1992), "Universals in the content and structure of values: Theoretical advances and empirical test in 20 countries", Advances in Experimental Social Psychology, Vol. 25, pp. 1-64. 
Sen, S. and Bhattacharya, C.B. (2001), "Does doing good always lead to doing better? Consumer reactions to corporate social responsibility", Journal of Marketing Research, Vol. 38, pp. 225-243.

Simkin, L. (2008), “Achieving market segmentation from B2B sectorisation”, Journal of Business and Industrial Marketing, Vol. 23 No. 7, pp. 464-474.

Sirdeshmukh, D., Singh, J. and Sabol, B. (2002), "Consumer trust, value, and loyalty in relational exchanges", Journal of Marketing, Vol. 66, pp. 15-37.

Stanaland, A.J., Lwin, M.O. and Murphy, P.E. (2011), “Consumer perceptions of the antecedents and consequences of corporate social responsibility", Journal of Business Ethics, Vol. 102 No. 1, pp. 47-55.

Swaen, V. and Chumpitaz, R.C. (2008), "Impact of corporate social responsibility on consumer trust", Recherche et Applications en Marketing (English edition), Vol. 23 No. 4, pp. 7-34.

Tian, Z., Wang, R. and Yang, W. (2011), “Consumer responses to corporate social responsibility (CSR) in China”, Journal of Business Ethics, Vol. 101 No. 2, pp. 197212.

Till, B.D. and Nowak, L.I. (2000), “Toward effective use of cause-related marketing alliances", Journal of Product and Brand Management, Vol. 9 No. 7, pp. 472-484.

van de Ven, B. (2008), “An ethical framework for the marketing of corporate social responsibility”, Journal of Business Ethics, Vol. 82 No. 2, pp. 339-352.

Varadarajan, P.R. and Menon, A. (1988), “Cause-related marketing: A coalignment of marketing strategy and corporate philanthropy", Journal of Marketing, Vol. 52 No. 3, pp. 58-74. 
Venkatraman, M. and Price, L. (1990), "Differentiating between cognitive and sensory innovativeness: Concepts, measurements and implications", Journal of Business Research, Vol. 20, pp. 293-315.

Wasson, C.R. (1978), Dynamic Competitive Strategy and Product Life Cycles, Austin Press, Austin, TX.

\section{APPENDIX}

\section{Insert Table 6 here}




\begin{tabular}{|c|c|c|}
\hline INSTITUTION & YEAR & INTERNATIONAL INITIATIVES \\
\hline $\begin{array}{l}\text { Organisation for Economic Co-operation and } \\
\text { Development (OECD) }\end{array}$ & 1976 & $\begin{array}{l}\text { OECD Guidelines for Multinational } \\
\text { Enterprises -revised in } 2000-\end{array}$ \\
\hline International Labour Organization (ILO) & 1976 & $\begin{array}{l}\text { Declaración Tripartita de la OIT sobre } \\
\text { las empresas multinacionales y la } \\
\text { política social }\end{array}$ \\
\hline \multirow{4}{*}{ United Nations (UN) } & 1991 & $\begin{array}{l}\text { Principles for Responsible Investment } \\
\text { UNEP-FI }\end{array}$ \\
\hline & 1999 & Global Compact \\
\hline & 1999 & $\begin{array}{l}\text { Global Sullivan Principles of } \\
\text { Corporate Social Responsibility }\end{array}$ \\
\hline & 2003 & Convention against corruption \\
\hline CSR Europe & 1995 & (-) Debate Forum (private initiative) \\
\hline $\begin{array}{l}\text { World Business Council for Sustainable } \\
\text { Development (WBCSD) }\end{array}$ & 1997 & (-) Debate Forum (private initiative) \\
\hline $\begin{array}{l}\text { Coalition for Environmentally Responsible } \\
\text { Economies (CERES) and the United Nations } \\
\text { Environment Programme (PNUMA) }\end{array}$ & 1997 & $\begin{array}{l}\text { Global Reporting Initiative (GRI) - } \\
\text { independent organization since 2002- }\end{array}$ \\
\hline Global Reporting Initiative (GRI) & 2000 & $\begin{array}{l}\text { Financial services sector supplement - } \\
\text { revised in } 2002-\end{array}$ \\
\hline European Union (EU) & 2001 & $\begin{array}{l}\text { Green Paper - Promoting a European } \\
\text { framework for Corporate Social } \\
\text { Responsibility }\end{array}$ \\
\hline $\begin{array}{l}\text { International Financial Corporation (IFC) - } \\
\text { World Bank- }\end{array}$ & 2002 & Equator Principles \\
\hline $\begin{array}{l}\text { International Organization for } \\
\text { Standardization (ISO) }\end{array}$ & 2010 & ISO 26000 \\
\hline INSTITUTION & YEAR & SPANISH INITIATIVES \\
\hline $\begin{array}{l}\text { Fundación Étnor para la Ética de los } \\
\text { Negocios y de las Organizaciones }\end{array}$ & 1994 & (-) Debate Forum (private initiative) \\
\hline Fundación Empresa y Sociedad & 1995 & (-) Debate Forum (private initiative) \\
\hline Fundación Entorno & 1995 & (-) Debate Forum (private initiative) \\
\hline Club de Excelencia en Sostenibilidad & 2002 & (-) Debate Forum (private initiative) \\
\hline \multirow{3}{*}{ Ministerio de Trabajo y Asuntos Sociales } & 2005 & Libro Blanco sobre RSE \\
\hline & 2005 & Observatorio de RSE \\
\hline & 2005 & Foro de Expertos de RSE \\
\hline Foro de Reputación Corporativa (Forética) & 2005 & Norma SGE 21:2005 \\
\hline $\begin{array}{l}\text { Comisión Nacional del Mercado de Valores } \\
\text { (CNMV) }\end{array}$ & 2006 & $\begin{array}{l}\text { Código Unificado de } \\
\text { Recomendaciones sobre Buen } \\
\text { Gobierno }\end{array}$ \\
\hline
\end{tabular}

TABLE 1. The development of CSR initiatives in Europe and Spain 


\begin{tabular}{lll}
\hline \hline Variable & Collectivists & Innovative customers \\
\hline \hline Gender & $46.7 \%$ Male & $48.8 \%$ Male \\
& $53.3 \%$ Female & $51.2 \%$ Female \\
\hline Age & $31.1 \%$ under 44 & $62.7 \%$ under 44 \\
& $68.9 \%$ 45 or over 45 & $37.3 \% 45$ or over 45 \\
\hline Marital status & $17.1 \%$ Single & $6.6 \%$ Single \\
& $58.3 \%$ Married & $36.7 \%$ Married \\
& $24.6 \%$ Other & $16.7 \%$ Other \\
\hline Educational level & $37.7 \%$ Primary studies & $11.7 \%$ Primary studies \\
& $36.8 \%$ Secondary studies & $42.1 \%$ Secondary studies \\
& $25.4 \%$ University degree & $46.2 \%$ University degree \\
\hline Occupation & $33.3 \%$ Full-time worker & $45.8 \%$ Full-time worker \\
& $4.4 \%$ Student & $17.8 \%$ Student \\
& $32.5 \%$ Retired & $10 \%$ Retired \\
& $11.6 \%$ Homemaker & $5 \%$ Homemaker \\
& $18.2 \%$ Other & $21.4 \%$ Other \\
\hline Salary & $31.1 \%$ Below $1.200 €$ & $23 \%$ Below $1.200 €$ \\
& $21.3 \% 1.201 €-1.800 €$ & $24.7 \% 1.201 €-1.800 €$ \\
\hline \hline
\end{tabular}

TABLE 2. Customer profile 


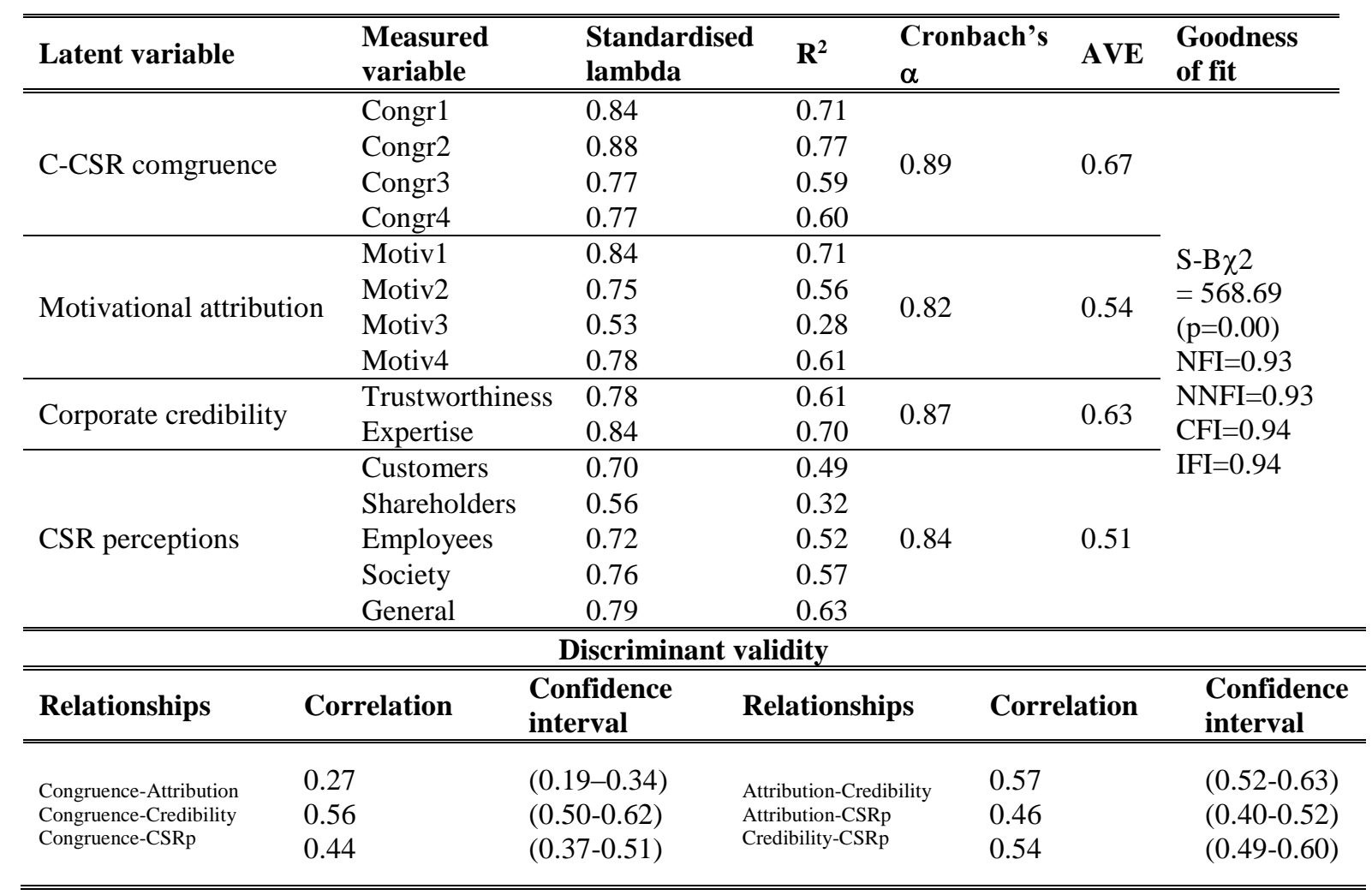

TABLE 3. First-order CFA for the global model of CSR perceptions 


\begin{tabular}{lllll}
\hline \hline Hypotheses & Causal relationship & Std. coefficient & T-value & Relationship \\
\hline \hline H1 & Congruence $\rightarrow$ Attribution & 0.27 & $7.07^{*}$ & Accepted \\
H2 & Congruence $\rightarrow$ Credibility & 0.44 & $10.91^{*}$ & Accepted \\
H3 & Attribution $\rightarrow$ Credibility & 0.46 & $12.85^{*}$ & Accepted \\
H4 & Congruence $\rightarrow$ CSRp & 0.21 & $4.48^{*}$ & Accepted \\
H5 & Attribution $\rightarrow$ CSRp & 0.24 & $5.67^{*}$ & Accepted \\
H6 & Credibility $\rightarrow$ CSRp & 0.29 & $5.10^{*}$ & Accepted \\
\hline \hline
\end{tabular}

TABLE 4. Hypotheses testing (H1 to H6) 


\begin{tabular}{|c|c|c|c|c|c|}
\hline \multirow{2}{*}{ Hypotheses } & \multirow{2}{*}{ Causal relationship } & \multicolumn{2}{|c|}{$\begin{array}{l}\text { Standardised coef. } \\
\end{array}$} & \multirow{2}{*}{$\begin{array}{l}\text { Dif } \chi^{2} \\
(1)\end{array}$} & \multirow{2}{*}{ Contrast } \\
\hline & & Conservatists & Innovative & & \\
\hline $\mathrm{H} 7 \mathrm{a}$ & Congruenc $\rightarrow$ Attribution & $0.32 *$ & $0.18^{*}$ & 1.61 & Rejected \\
\hline $\mathrm{H} 7 \mathrm{~b}$ & Congruenc $\rightarrow$ Credibility & $0.45^{*}$ & $0.34^{*}$ & 0.69 & Rejected \\
\hline $\mathrm{H} 7 \mathrm{c}$ & Congruence $\rightarrow$ CSRp & $0.30^{*}$ & $0.21 *$ & $3.50 * *$ & Rejected \\
\hline $\mathrm{H} 7 \mathrm{~d}$ & Attribution $\rightarrow$ Credibility & $0.42^{*}$ & $0.55 *$ & $3.32 * *$ & Accepted \\
\hline $\mathrm{H} 7 \mathrm{e}$ & Attribution $\rightarrow$ CSRp & $0.27 *$ & $0.15^{*}$ & $8.02 *$ & Rejected \\
\hline $\mathrm{H} 7 \mathrm{f}$ & Credibility $\rightarrow$ CSRp & 0.14 & $0.42 *$ & - & Accepted \\
\hline $\begin{array}{l}\text { Goodness } \\
\text { of fit }\end{array}$ & \multicolumn{5}{|c|}{$\begin{array}{l}\text { S-B } \chi 2=474.68(p<0.001) ; \mathrm{NFI}=0.93 ; \mathrm{NNFI}=0.96 ; \mathrm{CFI}=0.96 \\
\text { Dif. } \chi 2(4)=15.50(\mathrm{p}<0.01)\end{array}$} \\
\hline
\end{tabular}

TABLE 5. Hypotheses testing (H7a to H7f) 


\begin{tabular}{|c|c|}
\hline Variable & Items \\
\hline $\begin{array}{l}\text { C-CSR } \\
\text { congruence }\end{array}$ & $\begin{array}{l}\text { 1) Carrying out CSR initiatives is compatible with this institution's core } \\
\text { business; 2) It makes sense that this institution carries out CSR initiatives; } 3 \text { ) } \\
\text { Carrying out CSR initiatives is complementary to this institution's core } \\
\text { business; 4) There is a logical fit between the core business of this institution } \\
\text { and the CSR initiatives that it carries out }\end{array}$ \\
\hline $\begin{array}{l}\text { Motivational } \\
\text { attribution }\end{array}$ & $\begin{array}{l}\text { This company... } \\
\text { 1) Acts unselfishly; 2) Is altruistic; 3) Acts guided by the global benefit of its } \\
\text { stakeholders instead of by its self-interest; 4) Is generous }\end{array}$ \\
\hline $\begin{array}{l}\text { Corporate } \\
\text { credibility }\end{array}$ & $\begin{array}{l}\text { This company... } \\
\text { EXPERTISE: 1) Has a great expertise in corporate social responsibility; 2) Is } \\
\text { competent in the implementation of its responsibilities towards its } \\
\text { stakeholders; } \\
\text { TRUSTWORTHINESS: } 3 \text { ) Its commitment to its stakeholders is credible; 4) } \\
\text { Is honest about its commitment to its stakeholders }\end{array}$ \\
\hline $\begin{array}{l}\text { CSR } \\
\text { perceptions }\end{array}$ & $\begin{array}{l}\text { This company... } \\
\text { CUSTOMERS: 1) Establishes procedures to comply with customers' } \\
\text { complaints; 2) Treats its customers honestly; 3) Has employees who offer } \\
\text { complete information about corporate products/services to customers; 4) Uses } \\
\text { customers' satisfaction as an indicator to improve the product/service } \\
\text { marketing; 5) Make an effort to know customers' needs; } \\
\text { SHAREHOLDERS AND SUPERVISING BOARDS: 6) Tries to maximize } \\
\text { its profits; 7) Keep a strict control over its costs; 8) Tries to insure its survival } \\
\text { and long-term success; } \\
\text { EMPLOYEES: 9) Pays fair salaries to its employees; 10) Offers safety at } \\
\text { work to its employees; 11) Treats its employees fairly (without discrimination } \\
\text { or abuses); 12) Offers training and career opportunities to its employees; 13) } \\
\text { Offers a pleasant work environment (e.g., flexible hours, conciliation); } \\
\text { SOCIETY: 14) Helps solving social problems; 15) Uses part of its budget for } \\
\text { donations and social projects to advance the situation of the most unprivileged } \\
\text { groups of the society; 16) Contributes money to cultural and social events } \\
\text { (e.g., music, sports); 17) Plays a role in the society beyond the economic } \\
\text { benefits generation; 18) Is concerned with improving the general well-being } \\
\text { of society; 19) Is concerned with respecting and protecting the natural } \\
\text { environment; } \\
\text { GENERAL: 20) Always respects rules and regulations defined by law; 21) Is } \\
\text { concerned with fulfilling its obligations vis-à-vis its shareholders, suppliers, } \\
\text { distributors and other agents with whom it deals; 22) Is committed to well } \\
\text { established ethic principles }\end{array}$ \\
\hline $\begin{array}{l}\text { Novelty } \\
\text { seeking }\end{array}$ & $\begin{array}{l}\text { STIMULATION: 1) I like trying new things; 2) I like the challenge of doing } \\
\text { something that I have never done before; } \\
\text { SELF-DIRECTION: } 3 \text { ) I like having an exciting life; 4) In my life, I am } \\
\text { always searching for exciting and stimulating things }\end{array}$ \\
\hline
\end{tabular}

TABLE 6. Measurement scales 


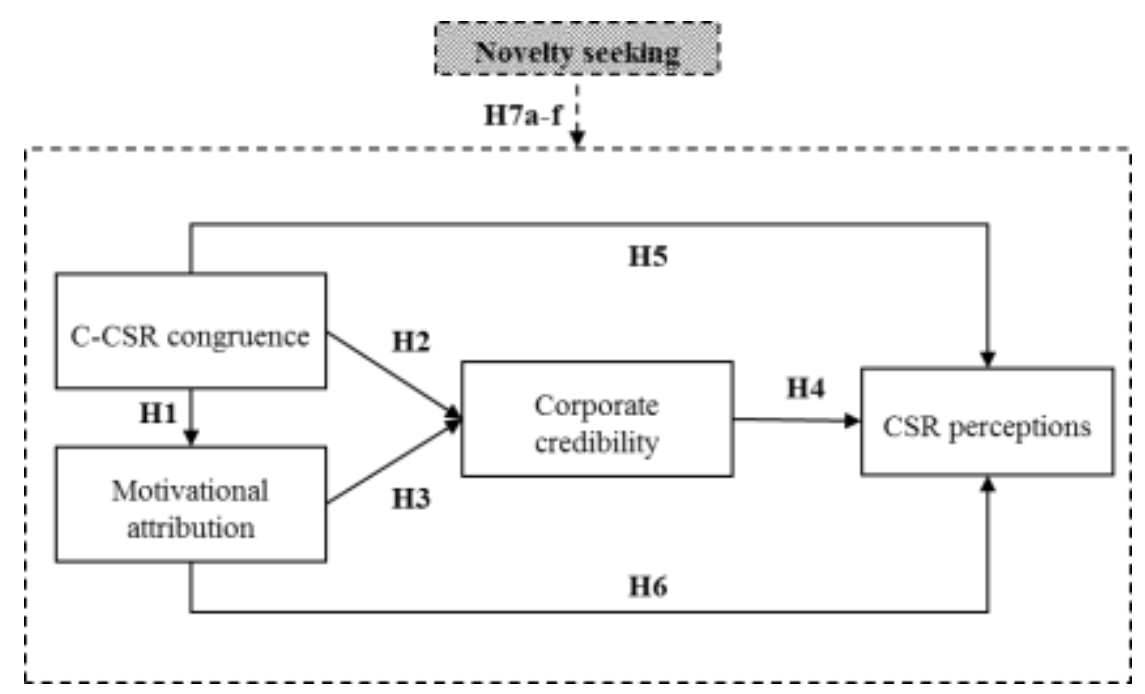

FIGURE 1. Conceptual model 